\title{
PERSATUAN DAN KESATUAN BANGSA DALAM NEGARA KESATUAN REPUBLIK INDONESIA
}

\author{
Oleh: \\ Elpi Lutpiani
}

\begin{abstract}
ABSTRAK
Persatuan secara sederhana berarti gabungan (ikatan, kumpulan, dan sebagainya) dari beberapa bagian menjadi sesuatu yang utuh. Dengan kata lain, persatuan itu berkonotasi disatukannya bermacam-macam corak yang beragam ke dalam suatu kebulatan yang utuh. Negara Indonesia adalah negara kesatuan berbentuk republik yang wilayahnya merupakan kesatuan dari ribuan pulau. Negara Indonesia terletak di antara Samudera Pasifik dan Samudera Hindia serta di antara Benua Asia dan Australia. Ada tiga faktor yang dapat memperkuat persatuan dan kesatuan dalam Negara Kesatuan Republik Indonesia. Ketiga faktor tersebut adalah Sumpah Pemuda, Pancasila, dan semboyan Bhinneka Tunggal Ika.
\end{abstract}

Keyword: Persatuan, Kesatuan Bangsa

\section{Latar Belakang}

Pada tahun 1850, George Windsor Earl seorang etnolog Inggris mengusulkan istilah Indunesians dan preferensi Malayunesians untuk penduduk kepulauan Hindia atau Malayan Archipelago. Kemudian seorang mahasiswa bernama Earl James Richardison Logan menggunakan Indonesia sebagai sinonim untuk Kepulauan Hindia. Namun di kalangan akademik Belanda, di Hindia Timur enggan menggunakan Indonesia. Sebaliknya, mereka menggunakan istilah Melayu Nusantara (Malaische Archipel).

Sejak tahun 1900 nama Indonesia menjadi lebih umum di kalangan akademik di luar Belanda. Golongan nasionalis Indonesia menggunakan nama Indonesia untuk ekspresi politiknya. Adolf Bastian dari Universitas Berlin memopulerkan nama Indonesia melalui bukunya Indonesien oder die inseln des malayischen arcipels (1884-1894). Kemudian sarjana bahasa Indonesia pertama yang menggunakan nama Indonesia adalah Suwardi Suryaningrat 
(Ki Hajar Dewantara) ketika ia mendirikan kantor berita di Belanda dengan nama Indonesisch Pers-Bureau di tahun 1913.

Kita mesti bersyukur kepada Tuhan Yang Maha Esa karena telah menakdirkan kita sebagai warga negara Indonesia. Indonesia adalah sebuah bangsa dan negara besar yang harus kita banggakan. Indonesia mempunyai wilayah yang luas, kekayaan alam yang melimpah, suku bangsa dan bahasa yang beraneka ragam. Tetapi semua itu dapat dipersatukan dalam sebuah ikatan Negara Kesatuan Republik Indonesia. Indonesia juga mempunyai sejarah yang membanggakan, kemerdekaan yang kita raih bukanlah hadiah dari penjajah. Tetapi kita menjadi bangsa yang memerdekakan dirinya sendiri. Indonesia memproklamirkan dirinya sebagai sebuah negara merdeka. Itu semua menjadi keunggulan bangsa Indonesia.

Proklamasi Kemerdekaan pada tanggal 17 Agustus 1945 telah mengakhiri rentetan penderitaan bangsa Indonesia sebagai bangsa yang terjajah. Proklamasi telah melahirkan Indonesia sebagai negara baru yang mempunyai kedudukan sejajar dengan bangsa lainnya yang telah merdeka terlebih dahulu. Proklamasi Kemerdekaan tidak akan pernah terjadi apabila tidak adanya persatuan dan kesatuan di antara warga negara Indonesia. Persatuan dan kesatuan bangsa harus selalu kita jaga, supaya Negara Kesatuan Republik Indonesia tetap menunjukkan eksistensinya dan menjadi negara mandiri yang terbebas dari berbagai intervensi atau campur tangan asing.

\section{Kasus Masalah}

Berdasarkan latar belakang di atas, maka kasus masalah yang akan dibahas di dalam makalah ini adalah sebagai berikut: 1) Apa makna persatuan dan kesatuan bangsa? 2) Bagaimana kehidupan bernegara dalam konsep Negara Kesatuan Republik Indonesia (NKRI)? 3) Apa saja faktor pendorong persatuan dan kesatuan bangsa Indonesia? 4) Apa saja faktor penghambat persatuan dan kesatuan bangsa Indonesia?

\section{Tinjauan Pustaka}

Kesatuan bangsa Indonesia yang kita rasakan saat ini, itu terjadi dalam proses yang dinamis dan berlangsung lama, karena persatuan dan kesatuan bangsa terbentuk dari proses yang tumbuh dari unsur-unsur sosial budaya masyarakat Indonesia sendiri, yang ditempa dalam jangkauan waktu yang lama sekali.

Unsur-unsur sosial budaya itu antara lain seperti sifat kekeluargaan dan jiwa gotongroyong. Kedua unsur itu merupakan sifat-sifat pokok bangsa Indonesia yang dituntun oleh asas kemanusiaan dan kebudayaan. Karena masuknya kebudayaan dari luar, maka terjadi proses akulturasi (percampuran kebudayaan). Kebudayaan dari luar itu adalah kebudayaan Hindu, Islam, Kristen dan unsur-unsur kebudayaan lain yang beraneka ragam. Semua unsur-unsur 
kebudayaan dari luar yang masuk diseleksi oleh bangsa Indonesia. Jadi makna dan pentingnya persatuan dan kesatuan bangsa dapat mewujudkan sifat kekeluargaan, jiwa gotong-royong, musyawarah dan lain sebagainya.

Tahap-tahap pembinaan persatuan bangsa Indonesia itu yang paling menonjol ialah sebagai berikut:

1. Perasaan senasib

2. Kebangkitan Nasional

3. Sumpah Pemuda

4. Proklamasi Kemerdekaan

\section{Pembahasan}

\section{Konsep NKRI menurut Undang-Undang Dasar Negara Republik Indonesia Tahun 1945}

Perubahan UUD Negara Republik Indonesia Tahun 1945 mengukuhkan keberadaan Indonesia sebagai negara kesatuan dan menghilangkan keraguan terhadap pecahnya Negara Kesatuan Republik Indonesia. Pasal-pasal dalam Undang-Undang Dasar Negara Republik Indonesia Tahun 1945 telah memperkukuh prinsip NKRI dan tidak sedikit pun mengubah NKRI menjadi negara federal.

Pasal 1 ayat (1) UUD Negara Republik Indonesia Tahun 1945 yang merupakan naskah asli mengandung prinsip bahwa "Negara Indonesia ialah negara kesatuan, yang berbentuk Republik." Pasal yang dirumuskan oleh Panitia Persiapan Kemerdekaan Indonesia tersebut merupakan tekad bangsa Indonesia yang menjadi sumpah anak bangsa pada 1928 yang dikenal dengan Sumpah Pemuda yaitu satu tanah air, satu bangsa, satu bahasa yaitu Indonesia.

Wujud Negara Kesatuan Republik Indonesia semakin kukuh setelah dilakukan perubahan UUD Negara Republik Indonesia Tahun 1945. Perubahan tersebut dimulai dari adanya ketetapan Majelis Permusyawaratan Rakyat yang salah satunya adalah tidak mengubah Pembukaan UUD Negara Republik Indonesia Tahun 1945 dan tetap mempertahankan Negara Kesatuan Republik Indonesia sebagai bentuk final negara bagi bangsa Indonesia.

Kesepakatan untuk tetap mempertahankan bentuk negara kesatuan didasari pertimbangan bahwa negara kesatuan adalah bentuk yang ditetapkan sejak awal berdirinya negara Indonesia. Bentuk negara kesatuan dipandang paling tepat untuk mewadahi ide persatuan sebuah bangsa yang majemuk ditinjau dari berbagai latar belakang (dasar pemikiran). UUD Negara Republik Indonesia Tahun 1945 secara nyata mengandung semangat agar Indonesia bersatu, baik sebagaimana tercantum dalam Pembukaan maupun dalam pasalpasal yang langsung menyebutkan tentang Negara Kesatuan Republik Indonesia. 
Hal ini dituangkan dalam lima Pasal, yaitu: pasal 1 ayat (1), pasal 18 ayat (1), pasal 18B ayat (2), pasal 25A, dan pasal 37 ayat (5) UUD Negara Republik Indonesia Tahun 1945 serta rumusan pasal-pasal yang mengukuhkan Negara Kesatuan Republik Indonesia, dan keberadaan lembaga-lembaga dalam Undang-Undang Dasar Negara Republik Indonesia Tahun 1945. Prinsip kesatuan dalam Negara Kesatuan Republik Indonesia dipertegas dalam alinea keempat Pembukaan UUD Negara Republik Indonesia Tahun 1945 yaitu “.... dalam upaya membentuk suatu Pemerintahan negara Indonesia yang melindungi segenap bangsa Indonesia dan seluruh tumpah darah Indonesia".

Pembentukan pemerintahan negara Indonesia yang melindungi segenap bangsa Indonesia dan seluruh tumpah darah Indonesia bertujuan untuk memajukan kesejahteraan umum, mencerdaskan kehidupan bangsa, dan ikut melaksanakan ketertiban dunia yang berdasarkan kemerdekaan, perdamaian abadi, dan keadilan sosial. Tujuan tersebut dapat dicapai hanya dengan adanya kemerdekaan bagi bangsa Indonesia. Dalam alinea keempat ini secara tegas diproklamirkan:

"maka disusunlah kemerdekaan kebangsaan Indonesia itu dalam suatu Undang-Undang Dasar negara Indonesia, yang terbentuk dalam suatu susunan negara Republik Indonesia yang berkedaulatan rakyat dengan berdasar kepada Ketuhanan Yang Maha Esa, Kemanusiaan yang adil dan beradab, persatuan Indonesia, dan kerakyatan yang dipimpin oleh hikmat kebijaksanaan dalam permusyawaratan/perwakilan, serta dengan mewujudkan suatu keadilan sosial bagi seluruh rakyat Indonesia".

Makna negara Indonesia juga dapat dipandang dari segi kewilayahan. Pasal 25A UUD Negara Republik Indonesia Tahun 1945 menentukan bahwa "Negara Kesatuan Republik Indonesia adalah sebuah negara kepulauan yang berciri Nusantara dengan wilayah yang batas-batas dan hak-haknya ditetapkan dengan undang-undang”. Istilah Nusantara dalam ketentuan tersebut dipergunakan untuk menggambarkan kesatuan wilayah perairan dan gugusan pulau-pulau Indonesia yang terletak di antara Samudera Pasifik dan Samudera Hindia serta di antara Benua Asia dan Benua Australia. Kesatuan wilayah tersebut juga mencakup 1) kesatuan politik; 2) kesatuan hukum; 3) kesatuan sosial-budaya; serta 4) kesatuan pertahanan dan keamanan. Dengan demikian, meskipun wilayah Indonesia terdiri atas ribuan pulau, tetapi semuanya terikat dalam satu kesatuan negara yaitu Negara Kesatuan Republik Indonesia.

Dari uraian di atas dapat disimpulkan bahwa negara Indonesia adalah negara kesatuan berbentuk republik yang wilayahnya merupakan kesatuan dari ribuan pulau yang terletak di antara Samudera Pasifik dan Samudera Hindia serta di antara Benua Asia dan Australia. 


\section{Keunggulan Negara Kesatuan Republik Indonesia}

Indonesia adalah negara kepulauan. Hal ini dapat dibuktikan dari nama lain atau julukan terhadap Indonesia yaitu Nusantara, yang berarti di antara nusa atau di antara pulau. Jadi, Indonesia terdiri atas pulau-pulau. Disebut sebagai negara kepulauan karena jumlah pulau besar dan kecil yang tersebar di wilayah Indonesia sangat banyak yaitu mencapai ribuan pulau. Pulau-pulau tersebut terletak di persimpangan dunia yaitu di antara dua samudera dan dua benua. Begitu indahnya pulau-pulau yang terletak di wilayah Indonesia yang membujur di garis khatulistiwa sehingga diibaratkan "Untaian ratna mutu manikam atau zamrud khatulistiwa".

Sekalipun wilayah Indonesia meliputi pulau-pulau, tidak menjadikan bangsa Indonesia bercerai berai, namun keadaan tersebut justru menjadi perekat untuk semakin meningkatkan rasa persatuan dan kesatuan bangsa. Hal ini dikarenakan secara yuridis formal bangsa Indonesia telah mempunyai landasan yang kuat, misalnya dinyatakan dalam Pembukaan UUD Negara Republik Indonesia Tahun 1945 alinea II. Selain itu, dalam Pasal 1 ayat (1) dinyatakan bahwa Indonesia ialah negara kesatuan yang berbentuk republik.

Dengan demikian, sekalipun secara nyata Indonesia terdiri dari berbagai keanekaragaman penduduknya yang tersebar di berbagai pulau besar dan kecil, tidak menjadikan bangsa Indonesia bercerai berai. Hal ini sudah barang tentu merupakan poin tersendiri yang menjadikan kita merasa bangga sebagai bangsa Indonesia. Melihat dan mencermati kondisi dan letak geografis wilayah Indonesia, sudah sewajarnyalah setiap insan yang merasa dirinya sebagai warga negara Indonesia mempunyai kebanggaan tersendiri. Bangga di sini dalam arti merasa berbesar hati atau merasa gagah karena mempunyai berbagai kelebihan atau keunggulan. Jadi, yang dimaksud bangga sebagai bangsa dan bertanah air Indonesia adalah merasa besar hati atau merasa berbesar jiwa atau merasa gagah sebagai bangsa Indonesia.

Konsekuensinya, kalau kita merasa bangga sebagai bangsa Indonesia, kita akan selalu berupaya menjunjung tinggi nama baik bangsa dan negara di mana pun kita berada. Kita juga akan selalu berupaya meningkatkan citra dan nama baik Indonesia melalui perbuatanperbuatan nyata di masyarakat, seperti tidak merusak hutan-hutan lindung, benda-benda bersejarah apalagi memperjualbelikannya, selalu menggunakan produk dalam negeri, dan sebagainya.

Negara Indonesia memiliki berbagai keunggulan. Keunggulan-keunggulan tersebut menurut Dadang Sundawa di antaranya sebagai berikut.

- Jumlah dan potensi penduduknya yang cukup besar yaitu menempati urutan keempat di dunia setelah RRC, India, dan Amerika Serikat. Jumlah penduduk yang besar 
merupakan potensi yang tidak ternilai harganya dalam upaya mengisi dan mempertahankan kemerdekaan, termasuk sebagai modal dasar dalam melaksanakan pembangunan dalam upaya menyejahterakan bangsa.

- Memiliki keanekaragaman dalam berbagai aspek kehidupan sosial budaya seperti adat istiadat, bahasa, agama, kesenian, dan sebagainya. Perbedaan atau keanekaragaman tersebut tidak menjadikan bangsa Indonesia bercerai-berai, namun justru merupakan potensi untuk mengembangkan dirinya menjadi bangsa yang besar. Hal ini juga didorong oleh adanya semangat persatuan dan kesatuan sehingga sekalipun terdapat perbedaan, namun bukan perbedaan yang ditonjolkan tetapi justru persamaannya.

-Dalam pengembangan wilayah, kita mempunyai konsep Wawasan Nusantara sehingga sekalipun terdapat berbagai keanekaragaman namun prinsipnya kita tetap satu pandangan yaitu memandang bangsa Indonesia sebagai satu kesatuan ideologi, politik, ekonomi, sosial budaya, dan hankam.

- Semangat sumpah pemuda yang selalu merasuki jiwa dan kalbu bangsa Indonesia. Dengan menunjukkan bahwa kita sama-sama memahami satu wilayah negara dan tanah air yang sama yaitu Indonesia; kita sama-sama merasa berbangsa yang satu bangsa Indonesia dan sama-sama menggunakan bahasa yang sama yaitu bahasa Indonesia serta memiliki sejarah yang sama yaitu sejarah Indonesia. Dalam pergaulan yang ditonjolkan adalah bangsa Indonesianya, bukan dari mana asal daerahnya.

- Memiliki tata krama atau keramahtamahan. Sejak dahulu bangsa Indonesia sangat terkenal akan keramahan dan kesopanannya sehingga sangat menarik bangsa-bangsa lain di dunia untuk datang ke Indonesia. Namun demikian, akhir-akhir ini norma kesopanan dan keramahan bangsa Indonesia agak tercemar oleh ulah segelintir manusia yang tidak bertanggung jawab, terutama yang gemar membuat kerusuhan, kerusakan, dan perangai-perangai lain yang justru membuat bangsa lain takut datang ke Indonesia.

- Letak wilayahnya yang amat strategis yaitu di posisi silang dunia sehingga membuat Indonesia menjadi wilayah yang amat ramai dan mudah untuk dikunjungi dan disinggahi oleh bangsa-bangsa lain.

- Keindahan alam Indonesia tidak disangsikan lagi, misalnya pantai-pantai di Bali (Pantai Kuta, Pantai Sanur, dan sebagainya), Sumatra (Danau Toba), Jawa Barat (Pantai Pangandaran, Pantai Carita, Gunung Tangkuban Perahu). 
Keanekaragaman flora dan fauna membuat bangsa Indonesia juga sering dikunjungi oleh bangsa-bangsa lain.

- Salah satu keajaiban dunia juga ada di Indonesia yaitu Candi Borobudur yang tidak sedikit menarik wisatawan untuk datang ke Indonesia. Selain candi Borobudur, Indonesia pun mempunyai keajaiban dunia lainnya yaitu Pulau Komodo.

-Wilayahnya sangat luas yaitu 5.193.250 Km2 yang meliputi daratan seluas 2.027.087 $\mathrm{Km} 2$ dan lautan seluas 3.166.163 Km2.

- Tanahnya amat subur dan kaya akan sumber alam.

Selain hal-hal di atas yang merupakan kondisi objektif bangsa Indonesia, maka secara internasional atau mendunia, bangsa Indonesia juga sudah beberapa kali dipercaya oleh bangsa-bangsa lain untuk menyelenggarakan pertemuan-pertemuan yang bersifat internasional yang juga tidak sedikit melahirkan sejarah bagi bangsa-bangsa lain. Kita masih ingat apa yang terjadi pada tahun 1955, di mana bangsa Indonesia dipercaya untuk menjadi tuan rumah dalam menyelenggarakan Konferensi Asia Afrika yang dampaknya sangat luas bagi bangsa-bangsa di wilayah Asia-Afrika dalam upaya memerdekakan diri dari belenggu penjajah, terutama yang masih belum merdeka saat itu.

Kita juga pernah dipercaya menjadi tuan rumah KTT Non-Blok pada tahun 1992 dan Indonesia juga termasuk perintis dan pendiri Gerakan Non-Blok tersebut. Selain itu, kita juga mempunyai pabrik pesawat terbang yang bernama PT Dirgantara Indonesia (dahulu bernama Industri Pesawat Terbang Nusantara/ IPTN) yang telah menghasilkan pesawat-pesawat yang dapat dibanggakan.

Sebagai bukti rasa cinta dan bangga yang sangat mendalam terhadap wilayah tanah air, banyak di antara seniman kita yang merefleksikannya dalam bentuk syair maupun lagu. Ada lagu yang berjudul "Rayuan Pulau Kelapa" yang diciptakan Ismail Marzuki, ada juga beberapa lagu karya Koes Plus yang diberi judul "Nusantara" dan "Kolam Susu” yang menggambarkan betapa indah dan suburnya keadaan alam Indonesia. Kesemuanya itu sudah barang tentu merupakan alasan yang sangat objektif untuk menjadikan kita merasa bangga sebagai bangsa Indonesia. Perasaan bangga sebagai bangsa Indonesia sudah barang tentu bukan hanya sekadar slogan belaka, akan tetapi harus dibuktikan dengan karya-karya nyata, baik dalam bentuk partisipasi dalam pembangunan maupun dalam bentuk karya-karya yang dihasilkannya.

\section{Faktor Pendorong Persatuan dan Kesatuan Bangsa Indonesia}

Persatuan dan kesatuan suatu negara merupakan faktor utama yang menentukan keberhasilan pembangunan yang dijalankannya. Begitu juga dengan Negara Kesatuan Republik Indonesia yang tengah melaksanakan pembangunan di segala bidang. Indonesia 
sangat memerlukan adanya persatuan dan kesatuan di antara rakyat Indonesia. Suatu program pembangunan tidak akan terlaksana dengan baik dan mencapai suatu keberhasilan jika kondisi negara terpecah belah atau tidak adanya persatuan dan kesatuan di antara warga negaranya. Dengan demikian, persatuan dan kesatuan Negara Kesatuan Republik Indonesia mempunyai peranan penting dalam menentukan keberhasilan pembangunan yang sedang dilaksanakan negara kita.

Selain dalam aspek pembangunan, persatuan dan kesatuan bangsa juga memegang peranan penting dalam meningkatkan harga diri bangsa di hadapan bangsa dan negara lain. Bangsa dan negara lain menghormati bangsa dan negara kita, serta tidak akan berani mencampuri urusan negara kita. Bangsa dan negara kita tidak akan mudah dipecah-belah dan diinjak-injak oleh negara lain, jika seluruh lapisan masyarakat memperkuat persatuan dan kesatuan bangsa. Jika negara kita terpecah belah tentu saja yang akan terjadi adalah negara kita akan dianggap sepele oleh bangsa dan negara lain, bahkan tidak menutup kemungkinan bangsa dan negara kita akan dijajah kembali oleh bangsa dan negara lain.

Persatuan dan kesatuan dalam Negara Kesatuan Republik Indonesia adalah hal yang mutlak dipertahankan dan terus diperkuat dalam seluruh aspek kehidupan. Kita harus menghindarkan diri dari perbuatan-perbuatan yang dapat menimbulkan perpecahan bangsa, misalnya merendahkan suku bangsa lain, menganggap sukunyalah yang paling baik, dan sebagainya. Kita harus memupuk persaudaraan dengan sesama warga negara Indonesia agar persatuan dan kesatuan bangsa senantiasa terjaga.

Ada tiga faktor yang dapat memperkuat persatuan dan kesatuan dalam Negara Kesatuan Republik Indonesia yaitu Sumpah Pemuda, Pancasila, dan semboyan Bhinneka Tunggal Ika. Ketiga faktor tersebut merupakan pemersatu seluruh bangsa Indonesia. Ketiga faktor tersebut dapat mempersatukan perbedaan dan keanekaragaman yang telah mewarnai kehidupan bangsa Indonesia. Perbedaan suku bangsa, agama, bahasa, dan sebagainya dapat dipersatukan dengan menjalankan nilai-nilai yang terdapat dalam ketiga faktor tersebut sehingga pada akhirnya nilai-nilai tersebut akan memperkuat persatuan dan kesatuan Negara Kesatuan Republik Indonesia.

\section{Sumpah Pemuda}

Sumpah Pemuda merupakan sumpah yang menunjukkan kebulatan tekad seluruh pemuda Indonesia yang merupakan unsur utama perjuangan bangsa dalam melawan penjajah untuk mempersatukan seluruh rakyat Indonesia dalam perjuangan meraih kemerdekaan. Dalam isi rumusan Sumpah Pemuda tersebut terkandung nilai utama yaitu satu tanah air, satu bangsa, dan satu bahasa yaitu Indonesia. Ikrar satu tanah air, satu bangsa, dan satu bahasa telah menjadi 
penyemangat bangsa Indonesia untuk bersatu. Ikrar ini juga telah memberikan manfaatmanfaat lainnya seperti mempererat hubungan kekeluargaan dan persaudaraan di antara bangsa Indonesia; membina kerukunan hidup dalam bermasyarakat, berbangsa dan bernegara; dan menumbuhkan kesadaran bahwa ancaman terhadap satu pulau atau daerah berarti ancaman bagi seluruh tanah air Indonesia. Ikrar inilah yang dapat memperkukuh persatuan dan kesatuan dalam Negara Kesatuan Republik Indonesia.

\section{Pancasila}

Pancasila dapat memperkukuh persatuan dan kesatuan dalam Negara Kesatuan Republik Indonesia. Hal itu dikarenakan nilai-nilai Pancasila bersifat universal atau menyeluruh. Artinya, nilai-nilai Pancasila tidak diciptakan hanya untuk satu suku bangsa saja. Nilai-nilai Pancasila juga tidak hanya diperuntukkan bagi penganut agama tertentu saja, akan tetapi nilainilai Pancasila berlaku dan menjadi pedoman hidup rakyat Indonesia tanpa memandang perbedaan suku bangsa, agama, budaya, bahasa, dan sebagainya. Dengan demikian, dapat dikatakan bahwa Pancasila dimiliki dan digunakan oleh semua unsur bangsa Indonesia.

\section{Bhinneka Tunggal Ika}

Bhinneka Tunggal Ika artinya walaupun berbeda-beda tetapi tetap satu jua. Inti dari semboyan Bhinneka Tunggal Ika adalah adanya persatuan dalam berbagai perbedaan. Kondisi bangsa Indonesia yang diliputi oleh berbagai perbedaan dapat dipersatukan salah satunya dengan melaksanakan makna semboyan Bhinneka Tunggal Ika. Persatuan dan kesatuan bangsa Indonesia akan senantiasa terjaga jika nilai-nilai dalam semboyan Bhinneka Tunggal Ika selalu dilaksanakan oleh rakyat Indonesia dalam pergaulan sehari-hari.

\section{Faktor Penghambat Persatuan dan Kesatuan Bangsa Indonesia}

Persatuan dan kesatuan bangsa merupakan syarat mutlak untuk memperoleh kemajuan bangsa. Akan tetapi dalam kenyataannya, kita sering melihat berbagai peristiwa yang mencerminkan gejala perpecahan bangsa seperti kerusuhan antarpendukung klub sepak bola, demonstrasi yang diwarnai aksi kekerasan, konflik antarsuku, dan sebagainya. Peristiwaperistiwa tersebut apabila tidak segera diatasi akan menyebabkan rusaknya persatuan dan kesatuan bangsa. Adapun faktor-faktor yang berpotensi menghambat persatuan dan kesatuan bangsa Indonesia di antaranya sebagai berikut.

\section{Kebhinnekaan/Keberagaman pada Masyarakat Indonesia}

Kondisi ini dapat menjadi penghambat persatuan dan kesatuan bangsa apabila tidak diiringi dengan sikap saling menghargai, menghormati, serta adanya toleransi yang telah menjadi karakter khas masyarakat Indonesia. Keberagaman tersebut dapat mengakibatkan 
munculnya perbedaan pendapat yang memicu lepas kendali, tumbuhnya perasaan kedaerahan yang berlebihan yang dapat memicu terjadinya konflik antardaerah atau antarsuku bangsa.

\section{Geografis}

Wilayah Indonesia yang terdiri dari pulau-pulau dan kepulauan memiliki karakteristik yang berbeda-beda. Kondisi ini dapat semakin memperlemah persatuan dan kesatuan bangsa apabila ketimpangan dan ketidakmerataan pembangunan dan hasil-hasil pembangunan masih belum dapat diatasi.

\section{Munculnya Gejala Etnosentrisme}

Etnosentrisme merupakan sikap menonjolkan kelebihan-kelebihan budayanya dan menganggap rendah budaya suku bangsa lain. Hal tersebut apabila tidak diatasi tentu saja akan memperlemah persatuan dan kesatuan bangsa.

\section{Melemahnya Nilai Budaya Bangsa}

Nilai-nilai budaya bangsa dapat melemah akibat kuatnya pengaruh budaya asing atau westernisasi budaya yang tidak sesuai dengan kepribadian bangsa, baik melalui kontak langsung maupun kontak tidak langsung. Kontak langsung antara lain melalui unsur-unsur pariwisata. Kontak tidak langsung antara lain melalui media cetak (majalah, tabloid), atau media elektronik (televisi, radio, film, internet, telepon seluler yang mempunyai fitur atau fasilitas lengkap).

\section{Pembangunan yang Tidak Merata}

Proses pembangunan yang terpusat di wilayah-wilayah tertentu dapat menimbulkan kesenjangan dalam berbagai bidang. Hal tersebut apabila tidak diselesaikan dapat memperlemah persatuan dan kesatuan bangsa.

\section{E. Perilaku yang Menunjukkan Sikap Menjaga Keutuhan Negara Kesatuan Republik Indonesia}

Sebagai warga negara yang baik tentu saja kita akan merasa bangga menjadi warga negara Indonesia yang diliputi berbagai keanekaragaman. Akan tetapi, keanekaragaman tersebut tidak menyebabkan bangsa dan negara Indonesia terpecah-belah, akan tetapi senantiasa bersatu padu. Tekad bangsa Indonesia untuk senantiasa merasa satu nusa, satu bangsa, dan satu bahasa. Ketika persatuan dan kesatuan bangsa sudah terwujud, maka keutuhan negara akan senantiasa terjaga.

Menjaga keutuhan Negara Kesatuan Republik Indonesia merupakan salah satu kewajiban dari setiap warga negara Indonesia. Sejak awal kemerdekaan para tokoh bangsa Indonesia telah membentengi diri dengan merumuskan dasar negara yaitu Pancasila. Pancasila 
dijadikan sebagai pandangan hidup dalam perilaku sehari-hari. Para pendiri negara menginginkan masyarakat Indonesia itu harus berketuhanan, berperikemanusiaan, mempunyai jiwa persatuan, demokratis, menjunjung tinggi musyawarah dalam mencapai mufakat, dan berkeadilan. Dengan mengamalkan nilai-nilai Pancasila, maka bangsa Indonesia akan selalu bersatu padu dan terhindar dari berbagai pertentangan dan perselisihan.

Nilai-nilai Pancasila harus diamalkan dalam kehidupan sehari-sehari sebagai upaya menjaga keutuhan negara. Nilai-nilai Pancasila dapat diamalkan dengan cara hidup rukun antarsesama. Kerukunan merupakan modal utama dalam menjaga keutuhan negara. Sikap tersebut dapat ditampilkan dalam kehidupan sehari-hari di rumah, di sekolah, dan di masyarakat.

1. Ketika berada di rumah, kita dapat menampilkan sikap rukun melalui perilaku saling menghormati dan menyayangi dengan anggota keluarga yang lain, tidak memaksakan kehendak kepada anggota keluarga yang lain, menghargai perbedaan pendapat, menjaga nama baik keluarga ketika bergaul dengan orang lain, dan sebagainya.

2. Dalam kehidupan di sekolah, senantiasa menampilkan sikap dan perilaku saling menolong dan saling berbagi dengan teman, menghargai dan menghormati pendapat teman, tidak membedakan-bedakan teman dalam bergaul, menghormati guru, dan sebagainya.

3. Dalam kehidupan di masyarakat, harus tetap menjaga kerukunan warga dengan sikap tolong-menolong, saling menjaga perasaan, saling menghormati, saling menghargai hak orang lain, tidak membeda-bedakan suku, agama dan daerah, bersikap arif, mau bekerja sama dengan orang lain, serta mau bekerja keras dalam membangun bangsa.

Sikap dan perilaku-perilaku yang disebutkan tadi harus diamalkan dalam kehidupan sehari-hari agar keutuhan Negara Kesatuan Republik Indonesia senantiasa terjaga.

\section{Kesimpulan}

Persatuan secara sederhana berarti gabungan (ikatan, kumpulan, dan sebagainya) dari beberapa bagian menjadi sesuatu yang utuh. Dengan kata lain, persatuan itu berkonotasi disatukannya bermacam-macam corak yang beragam ke dalam suatu kebulatan yang utuh.

Wawasan Nusantara adalah cara pandang dan sikap bangsa Indonesia terhadap diri dan lingkungannya dengan mengutamakan persatuan dan kesatuan bangsa serta kesatuan wilayah dalam penyelenggaraan kehidupan bermasyarakat, berbangsa, dan bernegara. Hakikat dari Wawasan Nusantara adalah kesatuan bangsa dan keutuhan wilayah Indonesia. 
Negara Indonesia adalah negara kesatuan berbentuk republik yang wilayahnya merupakan kesatuan dari ribuan pulau. Negara Indonesia terletak di antara Samudera Pasifik dan Samudera Hindia serta di antara Benua Asia dan Australia. Ada tiga faktor yang dapat memperkuat persatuan dan kesatuan dalam Negara Kesatuan Republik Indonesia. Ketiga faktor tersebut adalah Sumpah Pemuda, Pancasila, dan semboyan Bhinneka Tunggal Ika.

Menjaga keutuhan Negara Kesatuan Republik Indonesia merupakan salah satu kewajiban dari setiap warga negara Indonesia. Sejak awal kemerdekaan para tokoh bangsa Indonesia telah membentengi diri dengan merumuskan dasar negara yaitu Pancasila. Dengan mengamalkan nilai-nilai Pancasila maka bangsa Indonesia akan selalu bersatu padu dan terhindar dari berbagai pertentangan dan perselisihan.

\section{DAFTAR PUSTAKA}

Bakry, Noor Ms. 2009. Pendidikan Kewarganegaraan. Yogyakarta: Pustaka Pelajar.

Kementerian Pendidikan dan Kebudayaan. 2017. Pendidikan Pancasila dan Kewarganegaraan. Jakarta: Kementerian Pendidikan dan Kebudayaan.

Khor, Martin. 2003. Globalisasi Perangkap Negara-negara Selatan. Yogyakarta: Cinderelas Pustaka Rakyat Cerdas.

Lemhanas. 1997. Wawasan Nusantara. Jakarta: PT Balai Pustaka.

Sumaatmadja, Nursid. 2006. Manusia dalam Konteks Sosial, Budaya, dan Lingkungan Hidup. Bandung: Alfabeta.

Sundawa, Dadang. 2007. "Kerangka Sosial Budaya Masyarakat Indonesia dan Kebanggaan sebagai Bangsa Indonesia” dalam Materi dan Pembelajaran PKn SD. Jakarta: Universitas Terbuka.

Taniredja, Tukiran dan Kawan-kawan. 2009. Pendidikan Kewarganegaraan. Bandung: Alfabeta.

Wuryan, Sri dan Syaifullah. 2006. Ilmu Kewarganegaraan. Bandung: Laboratorium Pendidikan Kewarganegaraan Universitas Pendidikan Indonesia. 